\title{
Practical Research on the Undergraduate's Entrepreneurship in Local Universities
}

\author{
Yi Liu \\ School of Foreign Studies \\ Anhui Sanlian University \\ Hefei, China, 230601
}

\author{
Bingyan Zhi \\ School of Foreign Studies \\ Anhui Sanlian University \\ Hefei, China, 230601 \\ Liying Yan \\ School of Foreign Studies \\ Anhui Sanlian University \\ Hefei, China, 230601
}

\author{
Guiqing $\mathrm{Wu}$ \\ School of Foreign Studies \\ Anhui Sanlian University \\ Hefei, China, 230601 \\ Xiaohan Xu \\ School of Foreign Studies \\ Anhui Sanlian University \\ Hefei, China, 230601
}

\begin{abstract}
Based on the practical environment of university undergraduates 'entrepreneurship, this paper analyzes the internal and external factors that affect college students' entrepreneurship, and puts forward specific measures and suggestions on the cultivation of entrepreneurial ability of local undergraduates.
\end{abstract}

Keywords-local universities; entrepreneurship education; influencing factors; measures; suggestions

\section{INTRODUCTION}

On the issue of innovation and entrepreneurship of college students, its essence relates to "the cultivation of innovation and entrepreneurship", "social environmental factors" and "the application and results in practice." China's population base and the fact that college enrollment, decided to enter the job market every year, the employment situation of college graduates will become more and more serious, such as local undergraduate colleges, all over the country, cultivating most students, but due to local Government management, supported by local finance, brought about such as lack of funds, the level of education is not prominent, it is difficult to introduce high-level personnel and other issues. As a result, graduates from local undergraduate colleges face greater challenges in the job market. For this social environment by the support of innovative entrepreneurial projects should be the focus of local undergraduate institutions.

Fund Project: This paper is the research result that focused on national college students innovation and entrepreneurship training rogram "friends \& old Beijing court cheese cake" (Item Number: 201610959048）.

\section{The Local Undergraduate College Students ENTREPRENEURIAL ABILITY OF EXPLORATION}

Many colleges and universities use the geographical location of convenience, according to local conditions, support and encourage students to practice entrepreneurship. Yiwu Business School, for example, Yiwu Commodity City, relying on the network platform to carry out e-commerce business projects, and entrepreneurship education combined with widespread attention and praise. Throughout the country, Zhejiang Yiwu commercial base, geographical location, government policies, cultural atmosphere is to carry out the unique advantages of e-commerce conditions, internal and external environment to start their own business projects to take root to flourish. Therefore, how to develop suitable for our school, the region's actual situation of innovation and entrepreneurship capacity-building, innovation and entrepreneurship training institutions to explore whether the success of an important factor. As we all know, colleges and universities have four major functions: personnel training, dissemination of knowledge, scientific research, social services.

The course of this activity, innovation and entrepreneurship education fully integrated into the process of undergraduate talent training, combined with the advantages of the discipline and the characteristics of our school, contact the region's economic development trends and characteristics, so that from the cultural knowledge to practice The transformation of skills, widen the knowledge of students, opened the students to understand and try to open the door to unfamiliar areas, to enhance students' social, employment, business adaptability. It is concluded that the 
exploration of the innovation ability of the local undergraduate colleges should focus on:

- The establishment of the theoretical basis, practice for the purpose of establishing the theory and practice of comprehensive education innovation and entrepreneurship education;

- Constantly update the local social market demand, policies and regulations, forecast the development trend, targeted to carry out personnel training;

- Adhere to the surgery industry specializing in, training compound talents, improve the ability of students to adapt to achieve the campus and social transition;

- Interspersed in the classroom innovation and entrepreneurship cases, innovation and entrepreneurship seminars and training, students innovative sense of entrepreneurship, inspire students innovative business ideas.

\section{THE LOCAL UNDERGRADUATE COLLEGE STUDENTS BUSINESS IMPACT FACTORS}

\section{A. An Analysis of the Internal Factors of Undergraduates' Entrepreneurship in Local Universities.}

1) Entrepreneurship education: Students need to be improved awareness of business, such as in the treatment of professional and entrepreneurial relationship between the cognitive, and many students believe that entrepreneurship and the professional must be closely linked. But many entrepreneurs choose the venture is not the original choice of the professional, and they can achieve remarkable success. So that the direction of entrepreneurship is not necessarily consistent with the professional. But it does not mean that they choose to start their own business to give up the profession. College students not only need to have strong entrepreneurial theory knowledge, but also need to have relevant entrepreneurial practical experience. In the practice of entrepreneurship, the use of the professional way of thinking, to solve the problem. So the school to carry out the relevant business education for college students awareness of entrepreneurship has a great role in promoting. Colleges and universities to carry out a number of entrepreneurial education, that is, the need to set up relevant courses, but also need to establish practice base and other aspects of practice. The lack of practical experience of college students, student status is limited, the dynamic development of various industries and business information to grasp the inaccurate, can not find the right direction of selfentrepreneurship, and the phenomenon may occur is the entrepreneur of some hot industries blindly follow.

2) Business-related policies: Local government and the state issued by the relevant entrepreneurial policies, is the support and recognition of college students entrepreneurship. Excellent entrepreneurial policy greatly stimulated the enthusiasm of students, greatly improved the success rate of college students. In the case of college students' entrepreneurial rate increased year by year, the party and the government to entrepreneurship as one of the measures to ease the employment pressure of college students. In recent years, government departments have launched only for college students undergraduate entrepreneurship education and training center. And for education and training, Internet entrepreneurship and other industries, business costs low, there is no high threshold requirements, which undoubtedly become another impetus for college students entrepreneurship. So the entrepreneurial policy of college students has an undeniable role in entrepreneurship.On the basis of active reform of the first classroom experiment teaching, the second classroom activities have also been carried out, so that skills training, innovation activities, academic competitions, scientific research and so on will be fully penetrated into undergraduate teaching and students will be encouraged to participate in various practical activities. Three levels are based on the cognitive law, practice teaching is divided into basic practice teaching comprehensive practical teaching - innovative practice teaching three levels. "Combination of four" is a combination of theory and practice, in-class and extracurricular combination of practice and innovation, combining the school and outside the school. "Multimodule" is based on the students learning content, learning stage and practice teaching requirements, to break the boundaries of the laboratory, flexible composition of a number of practical teaching modules, so that students master the multi-disciplinary, multi-disciplinary knowledge and skills. "Open" is to fully open a variety of teaching and practice of resources and the environment, the implementation of open teaching and practice. Encourage and attract students to participate in a variety of useful practice, so that the laboratory as students practice and innovation activities, an important place. We implement the basic level of practical teaching. Combined with professional basic experimental course and professional experimental teaching, systematic strengthening of students basic skills training, so that students more solid and systematic grasp of professional basic experimental methods and techniques, including the classic traditional experimental methods and modern experimental techniques, familiar with conventional instruments and equipment Use, and has a good independent experimental ability and selflearning training initiative. Integrated practice teaching level, pay attention to mastery of multi-disciplinary, multidisciplinary knowledge and skills of the organic integration and comprehensive use, improve the comprehensive, design, research experiments proportion, thereby enhancing students' comprehensive experimental skills, analysis and problem-solving ability .

3) Venture Capital Problem: Many college students on the way to the lack of funds to hinder the project, leaving 
the project half-way or stagnant. So the financial problem is a headache, with the venture capital project promotion and operation, and then the profit stage, the funds can be withdrawn from circulation before they can further development and expansion of business projects.

4) Social environmental factors: The impact of venture enterprises, venture capital institutions and the community provided by the place is a hardware environment can not be ignored factors; and social stakeholders to support entrepreneurship is a key software environment factors. Social denial will discourage the enthusiasm of college students, with a negative attitude, it can not be innovative projects, it can not attract the public. This development continues, the project will not go on, and also can not drive up. So whether it is hardware or software environment factors, for entrepreneurship, have a huge impact.

\section{B. An Analysis of the Internal Factors of Undergraduates' Entrepreneurship in Local Universities.}

1) Undergraduates are in an important transition from theory to practice, from knowledge to entrepreneurship: College students' scientific and technological innovation and independent entrepreneurship are becoming more and more people's attention. However, independent entrepreneurship is a very challenging social activities, is the entrepreneur's own wisdom, courage and courage of the full range of tests. In addition to the individual's quality and ability to influence entrepreneurship, the school is also an important factor affecting college students one of the factors. The impact of the school on the independent entrepreneurship of university students can be divided into direct and indirect effects. Indirect impact from the school for college students to launch their own policies and a variety of teaching and training activities. Indirect impact refers to the school all the educational activities, especially in innovation and education reform as the main impact on students' business imperceptible influence. In recent years, colleges and universities have taken note of the impact of school education on student self-employment, and to take measures.

2) In the school of professional: Undeniably, in recent years, college students have obvious entrepreneurial intentions, but the entrepreneurial intentions of students in a variety of disciplines have some differences. Because of the characteristics of different disciplines, liberal arts students have lower entrepreneurial intentions than other subjects. After a questionnaire survey to Hefei University as an example: Liberal Arts students in the intention of students $45.6 \%$, not more than half. While science and engineering were $50 \%$ and $57.5 \%$, medical and even $70.6 \%$ of students have entrepreneurial intentions. This shows that technology is the capital of college students entrepreneurship, science and engineering disciplines is characterized by college graduates already have a basic operational technology, practicality, practicality are strong; and liberal arts focus on theoretical education, lack of practical ability. Therefore, it is one of the factors that influence college students' entrepreneurship. The school is to cultivate the base and fertile ground for university entrepreneurship, although in recent years, colleges and universities have recognized this, but the measures are often superficial, difficult to effect. Schools should be set from the curriculum, the relevant auxiliary conditions to proceed, especially the funds to promote college students entrepreneurship.

3) Curriculum:University for college students set up business courses and counseling, the school's philosophy and social development, the survey found that most needed, indicating that the idea of running a university is still traditional, and social development is slow, need from the concepts and measures Be updated to the forefront of the times. After the questionnaire survey, the demand for the course of entrepreneurship guidance, such as the writing format and skill of marketing, document writing and business plan, is as high as $76.2 \%$ and $69.9 \%$. Case study C students said: "Although I did not think of entrepreneurship, but I think the school curriculum should be more practical and operational-oriented.As of accounting and business etiquette, who are quite useful, the school should always carry out curriculum reform "Therefore, colleges and universities set up courses, should advance with the times, increase the supply of business guidance courses to meet the needs of students, and strive to implement.

4) Enhancing the Penetration of College Entrepreneurship Competition: In recent years, with the Challenge Cup Business Plan Competition publicity and held, college students began to focus on entrepreneurship contest, the questionnaire survey, the respondents, only $6.6 \%$ of the respondents, And $12.5 \%$ chose to participate in entrepreneurial knowledge contest and business plan competition, both the cumulative less than $20 \%$. Entrepreneurial Competition is the most influential entrepreneurial competition in China, which not only provides students with virtual entrepreneurial opportunities, so that students ability to improve and play to adapt to the virtual competition in the market; and the winning project in the game, into a real project, The real business. However, the survey results show that college students do not focus on entrepreneurship competition as their business preparation. Therefore, the need to improve the penetration of entrepreneurial competition, and effectively improve the degree of concern of college students.

\section{Financial Support for Start - up Start - up and Opening of Domestic Market}

Lack of entrepreneurial start-up is one of the biggest difficulties faced by college students entrepreneurs. After the survey, the survey participants set up business start-up sponsor of college students need $50.8 \%$ of the proportion of entrepreneurs, indicating the financial difficulties. As a school in order to establish the concept of college students entrepreneurial support, should be out of practical steps. Such as providing interest-free time to start a business start- 
up gold, funding college students entrepreneurship. Second, the opening of the school market, is conducive to actively create a good business environment, so that students in the school can initially try to compete in the venture, the accumulation of experience. To campus as a test base, look to the future business vision. We implement a combination of four teaching. To carry out the reform of theoretical courses and experimental courses, to update the content of experimental teaching, to improve the experimental syllabus and experimental instruction book of various courses, to reform experimental teaching methods and means to mobilize the initiative of student learning. Practice and innovation, the teaching content of the curriculum design with innovative nature of the teaching activities, students can cultivate the overall consciousness, logical thinking ability and interest in learning, but also exercise the students' independent work ability. For example, by improving the proportion of design and comprehensive design experiments, students are invited to participate in the development of experimental equipment, practical engineering projects and teachers' scientific research, so as to cultivate their practical ability and innovation ability. Combining active training with extracurricular activities, making the skills training, innovation activities, disciplinary competitions, scientific research and other activities into the practice of teaching, the students practice practical ability, engineering awareness, The spirit of innovation to cultivate radiation to the "second classroom" activities and activities, so that the formation of good interaction between classes and extracurricular. The school and outside the combination of scientific research institutes, enterprises, to establish a joint laboratory, joint scientific research projects, etc., will practice teaching work extended to enterprises and research institutes, so that students in-depth research institutes and enterprises, access to practical ability, Innovation and entrepreneurial ability to exercise.

\section{SPECIFIC MEASURES AND SUGGESTIONS ON THE UNDERTAKING ABILITY OF UNDERGRADUATES IN LOCAL UNIVERSITIES}

For students to provide better business information platform. College students in the early stages of business in all aspects are facing enormous obstacles and challenges. It is therefore important that the institutions provide the necessary support to students. Vigorously promote the country's entrepreneurial support policies for college students and the community for entrepreneurship, such as angel investment and favorable information. All help in the early days of entrepreneurship to reduce student financial pressure and ideological pressure at the same time increase the success rate of entrepreneurship. On the one hand, it is necessary to pay attention to the basic education of curriculum, and on the other hand, it can not ignore the cultivation of practical ability and the accumulation of experience in entrepreneurship practice. Curriculum education should be combined with a variety of innovative entrepreneurial activities, through various types of innovation and entrepreneurship activities and competitions, reinforce the theoretical knowledge of students, improve students' practical ability. At the same time in the total credits in the establishment of innovation and entrepreneurship education required credits, conditions are ripe gradually increased credits, revision of innovation and entrepreneurship activities credit management regulations, the student innovation and entrepreneurship activities into the innovation and entrepreneurship education credit system, the implementation of credit substitution system, Innovation and entrepreneurial landmarks to replace the graduation thesis and course system. Relying on local policies and resources advantages of newly established undergraduate colleges, and actively seek the support and help from all sides, expand financial education practice, innovation and entrepreneurship practice, social practice function in one of the university students practice education base construction efforts. And actively increase the school-enterprise cooperation, combining production and research, re-use of local economic development zones, science and technology parks and other resources for students to build professional practice base. All disciplines, the professional give full play to their advantages, relying on the school's professional platform, and actively establish links with the enterprise, the use of corporate funds and equipment for students to fully understand the business, in-depth industry opportunities, which will greatly benefit students entrepreneurial practice.

The Construction of Teaching Staff Can not Adapt to the Needs of Innovation and Entrepreneurship Education of College Students in the New Period - Particularly in Local Newly - built Universities. On the one hand, the local new undergraduate colleges and universities from the higher or higher vocational training, the overall teacher is very weak, from undergraduate teaching requirements are still relatively far, long-term in the "climbing" stage. In order to meet the Ministry of Education undergraduate teaching evaluation and other checks and examinations, local newly established undergraduate institutions in the introduction of talent can be described as spared no effort, make every effort. However, the introduction of talent mainly consider the subject construction and professional layout, very few will take into account the needs of innovation and entrepreneurship education; the other hand, in the local newly established undergraduate colleges engaged in innovation and entrepreneurship education teachers are mainly from the original teachers In recent years, the introduction of outstanding academic instructors to enrich the team to go, but still a lack of teaching experience, in general, the structural problems of contradictions are still prominent; the third in the third place, On the one hand, this is the teacher The body belongs to the traditional teaching as the main business of the teaching group, their own business experience, in the case of teaching and practical operation can not give students a true share of entrepreneurial stories, which will not only affect the enthusiasm of students for entrepreneurship, but also affect Students in the degree of trust of teachers, in this sense, it is bound to affect the effect of innovation and entrepreneurship education.

The school organizes those who are enthusiastic and creative students to participate in, local economic management department, park enterprises and advisory bodies to participate in the feasibility study of 
entrepreneurial model. Second, the investigation. By the school or human resources company in the form of a questionnaire on the establishment of entrepreneurship platform for college students (simulation business) for research. In the initial stage of the construction of the platform, students can start the preparation and trial run, and gradually set up college students in the school business association (by the employment guidance center or student union and business, investors) as college students entrepreneurship training and social practice management, Enterprises and schools to participate in the management, and students in the school business elective courses, as college students career guidance courses into the credit management. Finally, organizational training and entrepreneurial simulation, according to the business management model to guide students to business practice and business operations, students as temporary staff to serve as a position, mainly the use of summer vacations, holidays and weekends and other free time, as they To provide a specific business training college students series. Under the strict enterprise management system and the effective supervision and guidance of the school, the students' management ability and social ability will be improved, and the business model of the enterprise in the regional market will be improved and the excellent entrepreneurial talents will be selected. According to the student's work performance and business performance, their entrepreneurial ability to carry out an objective evaluation. In the annual business income in the extraction of $2 \%-3 \%$ of the funds as the University Entrepreneurship Award Fund, to reward outstanding students to participate in entrepreneurial exercise. Entrepreneurship education nurture entrepreneurs. To adapt to the local economic development of entrepreneurship education to local undergraduate colleges and universities to bring wisdom and wealth, more for the local economy exhibition into the dynamic. Entrepreneurship education and entrepreneurial practice will make the combination of college students in the broad road of life head high.

The Construction of Teaching Staff Can not Adapt to the Needs of Innovation and Entrepreneurship Education of College Students in the New Period - Particularly in Local Newly - built Universities. On the one hand, the local new undergraduate colleges and universities from the higher or higher vocational training, the overall teacher is very weak, from undergraduate teaching requirements are still relatively far, long-term in the "climbing" stage. In order to meet the Ministry of Education undergraduate teaching evaluation and other checks and examinations, local newly established undergraduate institutions in the introduction of talent can be described as spared no effort, make every effort. However, the introduction of talent mainly consider the subject construction and professional layout, very few will take into account the needs of innovation and entrepreneurship education; the other hand, in the local newly established undergraduate colleges engaged in innovation and entrepreneurship education teachers are mainly from the original teachers In recent years, the introduction of outstanding academic instructors to enrich the team to go, but still a lack of teaching experience, in general, the structural problems of contradictions are still prominent; the third in the third place, On the one hand, this is the teacher The body belongs to the traditional teaching as the main business of the teaching group, their own business experience, in the case of teaching and practical operation can not give students a true share of entrepreneurial stories, which will not only affect the enthusiasm of students for entrepreneurship, but also affect Students in the degree of trust of teachers, in this sense, it is bound to affect the effect of innovation and entrepreneurship education.

Entrepreneurial ability is a comprehensive ability, from the ability to grasp the needs of the market, the ability to capture opportunities for decision-making, capital raising financing capacity, the ability to form a team of personnel, organizational management coordination ability to adapt to environmental resilience, Affordability, ability to solve problems and practical ability to change the ability to innovate and other capabilities constitute. Based on this, the formation and strengthening of entrepreneurial ability only through classroom teaching, theoretical study, knowledge reserves, professional experiments or practice is far from achievable, but also an environment, a practice through the realization or verification of students a concept Environment, an innovative thinking can be transformed into a product development environment, a product can promote the market service environment, a potential to play a creative student of the characteristics of the ring environment, and this environment is the current personnel training system does not have and can not provide. Entrepreneurship is a very practical activity, all kinds of entrepreneurial knowledge only in practice can be used to reflect its value and significance. The cultivation of entrepreneurial ability depends not only on classroom learning but also on practice. Only by combining the knowledge of operation, management, financial management, and specialty in practice can students' entrepreneurial ability be cultivated. At present, the application of undergraduate colleges entrepreneurship education is mainly through the first classroom teaching to achieve, the second class is only a professional experiment and professional production practice, and entrepreneurial activity has nothing to do. This kind of education system lacks the space environment of a kind of entrepreneurial activity. Without this kind of environment, cultivating students' entrepreneurial ability is almost empty talk.

Innovation and entrepreneurship education is not simply a certain kind of knowledge or ability to upgrade, but need system design, system to promote the overall quality of the upgrade, for example, the education involved in innovation and business management, business management, marketing,We strengthen guidance at the institutional level. Encourage all professional teachers, employment counselors to actively carry out innovation and entrepreneurship education theory and case studies, and continuously improve the professional education, employment guidance in innovation and entrepreneurship education awareness and ability. To encourage teachers to take the initiative to strengthen their own practical skills to improve, take the "send out, please come in" way to strengthen the adjustment of knowledge structure, that is to take the new teachers sent to enterprises for one year corporate internships or attachment training to participate in social industry 
innovation Entrepreneurial practice. This makes up for young teachers from school to school, from theory to theory, but also make them familiar with the enterprise, improve the ability to solve practical problems; we employ entrepreneurs from all walks of life, entrepreneurial success, experts and scholars as part-time teachers, With its rich practical experience to guide students. At present, a combination of high-quality and innovative entrepreneurship education teachers have been formed. In the school year, we hold three "one innovation" activities, namely "an innovation contest", under the electronic design competition, mechanical design contest, robot contest, industrial design contest, professional support, competition for the project practice Team groups to stimulate students' awareness of innovation. "A communication forum", business alumni and students face to face dialogue, exchange business difficulties encountered, problems and successful experiences such as the introduction, to provide students with business reference and guidance. "A simulation practice", we hold a "cool street" activities, to encourage students to design their own products, take the bargaining approach, so that students self-service, practice, entrepreneurial ability. We apply for 100,000 yuan of funds to start a business incubation project, so that students interested in expertise and expertise to find the right combination between the points, feelings and experience entrepreneurship, enhance the spirit of innovation. The Enlightenment of Entrepreneurship Education in Social Practice. Innovative entrepreneurial talent training needs of scientific research and innovation and engineering innovation environment, we cooperate with enterprises through the production and research activities to build training base, settled in the government-run college Pioneer Park, the use of teachers of patent products to create entrepreneurial enterprises, students use the holidays "work", and enterprises, the use of commercial potential value of the design work to carry out business planning activities. By the colleges, communities, enterprises, the development of benign interactive entrepreneurial education ecosystem, is for future students laid the foundation for business

Administrative approval and other relevant professional knowledge, is a very complex systems engineering. Therefore, in promoting the innovation and entrepreneurship education of college students must deal with several relationships, which is the innovation and entrepreneurship education into higher education and professional education in colleges and universities to the first condition. The basic theory and basic knowledge of innovation and entrepreneurship education is important, but the essence of the innovation and entrepreneurship education of college students, the key is the practical ability - that is, "how" and "how to do" problem. Therefore, only in the educational activities to deal with the relationship between the two, scientific delineation of their proportion, a reasonable grasp of the mutual support between the two, can truly achieve the purpose of innovation and entrepreneurship education. In the local new undergraduate institutions, its undergraduate teaching system is not yet mature, is still in the exploration, especially the original from the Teachers College upgraded to the new undergraduate colleges, in the design of education and teaching links, always get out "Teacher Education "The shadow, attaches great importance to the theory of teaching, teaching methods also take a single indoctrination based on the theory of teaching. This problem must be resolved first, in the design of education and teaching activities should be considered when it comes to focus on practical ability to enhance the practice of innovation is the emphasis on education is the fundamental. The relationship between professional curriculum innovation and entrepreneurship education Innovative entrepreneurship education curriculum is with the development of the situation and the growing needs of students, and the addition of a professional course. At present, under the great environment of promoting innovation education in our country, local newly-built undergraduate colleges should try to popularize innovation and entrepreneurship education, regard innovation and entrepreneurship education as one of the contents of professional courses, improve students' knowledge structure,To mobilize students enthusiasm, to impart innovative skills to improve the employment capacity of college students to alleviate the current "employment difficult" status quo. Therefore, the local new undergraduate colleges should start from the low-grade students, and gradually the innovation and entrepreneurship education into the professional course learning, training students' awareness of innovation, and effectively improve the employability of students.

Focus on teamwork to encourage cross-professional inter-hospital cooperation projects. Sanlian College of Foreign Languages College, College of the Arts and Computer College in the commercial project. Give full play to the professional expertise of students of computer science, the use of modern technology to create publicity and sales platform, combining the language students and art students professional knowledge. The realization of the line plus the line under the Internet + new sales model.

Change the inherent concept of failure to attach importance to the case. And actively carry out entrepreneurial training to tap and integrate all kinds of resources, the appropriate introduction of social entrepreneurship inquiry. In the process of entrepreneurial education, institutions and mentors often focus on the success of the case analysis and learning. However, in practice, we found that the success of optical learning cases often make us the entrepreneurial practice problems appear too optimistic, so learning the experience of failure is particularly important. Institutions and tutors should try to connect the social reality, in the entrepreneurial lecture to add more cases of failure analysis, easy for students to sum up the failure of experience, to avoid disadvantages. So that college students in preparation for learning the early end of thinking, clear thinking in the early days of detours.

Extensive entrepreneurial activities and regularly organize the exchange of experience. For entrepreneurship education, the common practice of local colleges and universities is to carry out business competition, create business incubator base for college students to provide early education and material support. But often run out of steam, the lack of experience in the school business project summary and guidance. For the school to carry out 
entrepreneurial activities, we advocate learning in business, learning in the entrepreneurial model. Not only to encourage students to entrepreneurial activities, but also in the entrepreneurial activities carried out at the same time tracking, not only the organization of outstanding projects to learn, but also to experience the failure of the project summary.

\section{CONCLUSION}

In short, the local university innovation and entrepreneurship practice assessment system construction needs In practice, constantly revised and improved, so that the practice of innovation and entrepreneurship to develop a positive Of the role. At the same time, in the local university innovation and entrepreneurship practice assessment The process requires attention to two issues: First, the subjectivity of the evaluation, due to subjective. The existence of evaluation indicators, evaluation of individual preferences and the knowledge structure is often different Which leads to the difference of the evaluation results. Therefore, the selection of evaluation subjects should be diversified. The subjective evaluation of the weight should be controlled in a certain range; Second, the evaluation of The Development and Innovation of University Students' Innovative and Enterprising Practice in Local Colleges and Universities Industry education, professional education and other factors are closely related to its evaluation is bound by the relevant. Factors, such as different professional students, to accept different innovative entrepreneurship education Course students, in the practice of innovation and entrepreneurship training, the results will exist Differences, so the assessment of the practice of innovation and entrepreneurship must remove the relevant factors, impact, objective and independent evaluation.

\section{REFERENCES}

[1] Ju Yonggong university students entrepreneurship education research [J]. Educational Theory and Practice, 2014 (3): 11-12.

[2] Zhu Yanjie. Analysis of the status quo of domestic college students entrepreneurship education [J]. Sichuan Vocational and Technical College, 2014 (2): 95-97.

[3] Lin Peiyun. Comprehensive evaluation of entrepreneurial ability of college students [J]. Education and occupation, 2014 (2): 95-96.

[4] Lin Yin, Xie Zhiyuan.Undergraduate entrepreneurship education in the value of guidance $[\mathrm{J}]$. Innovation and entrepreneurship education, 2012 (2): 38-40.

[5] Robert D.Hisrich, Michael P.Peters, Dean A.Shepherd. Entrepreneurship Management (7th Edition) [M]. Beijing: Mechanical Industry Press, 2009 (5): 3.

[6] Wang Qianxin, Liu Xin. Study on the Operation Mechanism of Newly-built Undergraduate Colleges [M]. Beijing: Science Press, 2007 (11): $11 \sim 12$. 